\title{
Plastic Responses of Magnolia schiedeana Schltdl., a Relict-Endangered Mexican Cloud Forest Tree, to Climatic Events: Evidences from Leaf Venation and Wood Vessel Anatomy
}

\author{
Ernesto C. Rodríguez-Ramírez ${ }^{1}$, Jeymy Adriana Valdez-Nieto ${ }^{1}$, José Antonio Vázquez-García ${ }^{2} \oplus$, \\ Gregg Dieringer ${ }^{3}(-)$ and Isolda Luna-Vega ${ }^{1, *}$ \\ 1 Laboratorio de Biogeografía y Sistemática, Facultad de Ciencias, Universidad Nacional Autónoma de México, \\ Mexico City 04510, Mexico; echanes@ciencias.unam.mx (E.C.R.-R.); \\ jeymy-valdz@ciencias.unam.mx (J.A.V.-N.) \\ 2 Laboratorio de Ecosistemática, Instituto de Botánica, Departamento de Botánica y Zoología, Centro \\ Universitario de Ciencias Biológicas y Agropecuarias, Universidad de Guadalajara, km 15.5 carr. \\ Guadalajara-Nogales, Camino Ing. Ramón Padilla Sánchez 2100, Nextipac, Zapopan 45221, Jalisco, Mexico; \\ talaumaofeliae@gmail.com \\ 3 Department of Natural Sciences, Northwest Missouri State University, 800 University Dr., \\ Maryville, MO 64468, USA; greggd@nwmissouri.edu \\ * Correspondence: luna.isolda@gmail.com
}

Received: 20 May 2020; Accepted: 3 July 2020; Published: 7 July 2020

check for updates

\begin{abstract}
The Mexican tropical montane cloud forest trees occur under special and limited climatic conditions; many of these species are particularly more sensitive to drought stress. Hydric transport in leaf veins and wood features are influenced by climatic variations and individual intrinsic factors, which are essential processes influencing xylogenesis. We assessed the plastic response to climatic oscillation in two relict-endangered Magnolia schiedeana Schltdl. populations and associated the architecture of leaf vein traits with microenvironmental factors and wood anatomy features with climatic variables. The microenvironmental factors differed significantly between the two Magnolia populations and significantly influenced variation in M. schiedeana leaf venation traits. The independent chronologies developed for the two study forests were dated back 171-190 years. The climate-growth analysis showed that $M$. schiedeana growth is strongly related to summer conditions and growth responses to $\mathrm{T}_{\max }, \mathrm{T}_{\min }$, and precipitation. Our study highlights the use of dendroecological tools to detect drought effects. This association also describes modifications in vessel traits recorded before, during, and after drought events. In conclusion, our results advance our understanding of the leaf vein traits and wood anatomy plasticity in response to microenvironmental fluctuations and climate in the tropical montane cloud forest.
\end{abstract}

Keywords: drought event; leaf traits; tree-ring width; resilience; xylem vessel traits; tropical montane cloud forest

\section{Introduction}

The tropical montane cloud forests (TMCFs) represent one of the most important biodiversity hotspots on Earth due their high proportions of relict-endemic and endangered species [1-5]. Unfortunately, deforestation, habitat fragmentation (as a product of grazing, logging, and avocado plantations) are creating unprecedented pressures on the natural resources in most ecosystems [6-8]. Furthermore, drought events are expected to be greater in rate and magnitude than what has occurred thus far $[2,9]$. These climate events are considered to play a significant role in limiting TMCF tree 
species range at the macro and micro climatic scales [10]. Fog and/or mist can play a unique and varied role in TMCF plant ecology during drought events [5], partially affecting leaf vascular system adaptations (vein length, leaf shape, vein density, among others), growth rates (growth ring width and/or vessel modifications), and altering the resilience during specific climate events such as El Niño-Southern Oscillation (ENSO) [11-14]. The resilience of some TMCF trees to drought events may constitute an indirect response of the relict-tree species that depend on high moisture conditions. Mexican TMCF trees are adapted to high humidity during the rainy season (5000 and $6000 \mathrm{~mm}$ in the southeastern part of the country) and to the drought season (250-300 $\mathrm{mm}$ in the central and east) [15]. Notwithstanding, complex topography contributes to a substantial microclimatic variability at a fine scale, often resulting in mosaics of vegetation types within small geographic areas $[4,10,16]$.

Specifically, Magnolia schiedeana Schltdl. is considered an Oligocene-Miocene relict and endangered species under the Red List of Magnoliaceae [17] and the Red List of Mexican cloud forest trees [18] occupying less than $10 \%$ of their original range. Magnolia schiedeana is endemic to small TMCF fragments, which thrive on steep $\left(>25^{\circ}\right)$ rocky slopes and high moisture conditions of eastern Mexico [19]. This species produces simple leaves that are broadly elliptical, elliptic to oblong-elliptic or oblanceolate-elliptic in shape. Leaves are acute to acuminate at the apex and obtuse at the base with silica crystals in the epidermal cells and in the cuticle [20], which could decrease the probability of hydric stress during drought events [11]. In addition, the wood anatomy morphology is diffuse porous, which obscures the ring boundaries; notwithstanding, it is perceptible in a wood core well-sanded surface [13]. Diffuse porous are anatomical adaptations that grant a high performance in hydraulic conductance during climatic oscillations in TMCFs; nevertheless, the Magnolia's xylem vessels are randomly distributed within the tree-ring width.

An integral analysis involving leaf vein traits, dendroecology, and wood anatomy may provide insights into the specific climatic oscillations of TMCF tree species [11,21-23]. Studies on morphological leaf plasticity and wood anatomy appear to be key in assessing the plastic responses to climate events and resilience of tree species inhabiting a specific ecosystem [24-27].

The effects of microenvironmental and climatic oscillations on Magnolia schiedeana have not yet been assessed, and we do so by examining the leaf vein traits, annual tree rings, and vessel traits of individual Magnolia species in two TMCF in eastern Mexico. Our aims were to:

(1) evaluate the microenvironmental effect (litter depth, temperature and moisture soil, and canopy openness) on leaf vein traits (leaf shape, vein length, primary vein size, leaf base shape, leaf base angle, angle between major secondary veins and primary veins, and vein density);

(2) examine the relationship between tree-ring width and climatic fluctuations, and determine the effects of local climatic factors on the ring-width index of individual trees; and

(3) assess the influence of drought events on the plasticity of annual tree-ring width and vessel traits (density, hydraulic diameter, and percentage of conductive vessel area).

\section{Material and Methods}

\subsection{Study Forests}

The study involved two Mexican beech forests which support even-aged 152-168-year-old beech stands [28]. (1) Medio Monte locality, San Bartolo Tutotepec municipality $\left(20^{\circ} 24^{\prime} 50^{\prime \prime} \mathrm{N}, 98^{\circ} 14^{\prime} 24^{\prime \prime}\right.$ W; 1800-1944 $\mathrm{m}$ asl; mid temperatures $\left(16.5-21.8^{\circ} \mathrm{C}\right.$ ) and annual precipitation of 524-2100 mm); and (2) El Gosco locality, Tenango de Doria municipality $\left(20^{\circ} 19^{\prime} 37.8^{\prime \prime} \mathrm{N}, 98^{\circ} 14^{\prime} 57.1^{\prime \prime} \mathrm{W}\right.$; 1557-1864 m asl; mid temperatures $\left(14.5-22.48{ }^{\circ} \mathrm{C}\right)$; and annual precipitation of 524-1850) [28] both within the state of Hidalgo in eastern Mexico (Figure 1A). The study forests are characterized by the natural distribution area of Magnolia schiedeana Schltdl., which is an endangered-tropical montane cloud forest tree species, inhabiting steep slopes. The temperate climate is Cwb sensu Peel et al. [29]. Soils are mainly Spodosol to Andisol-humic (Th) with light sandy-clay loam texture possessing $\mathrm{pH}$ values from 4 to 6 . 


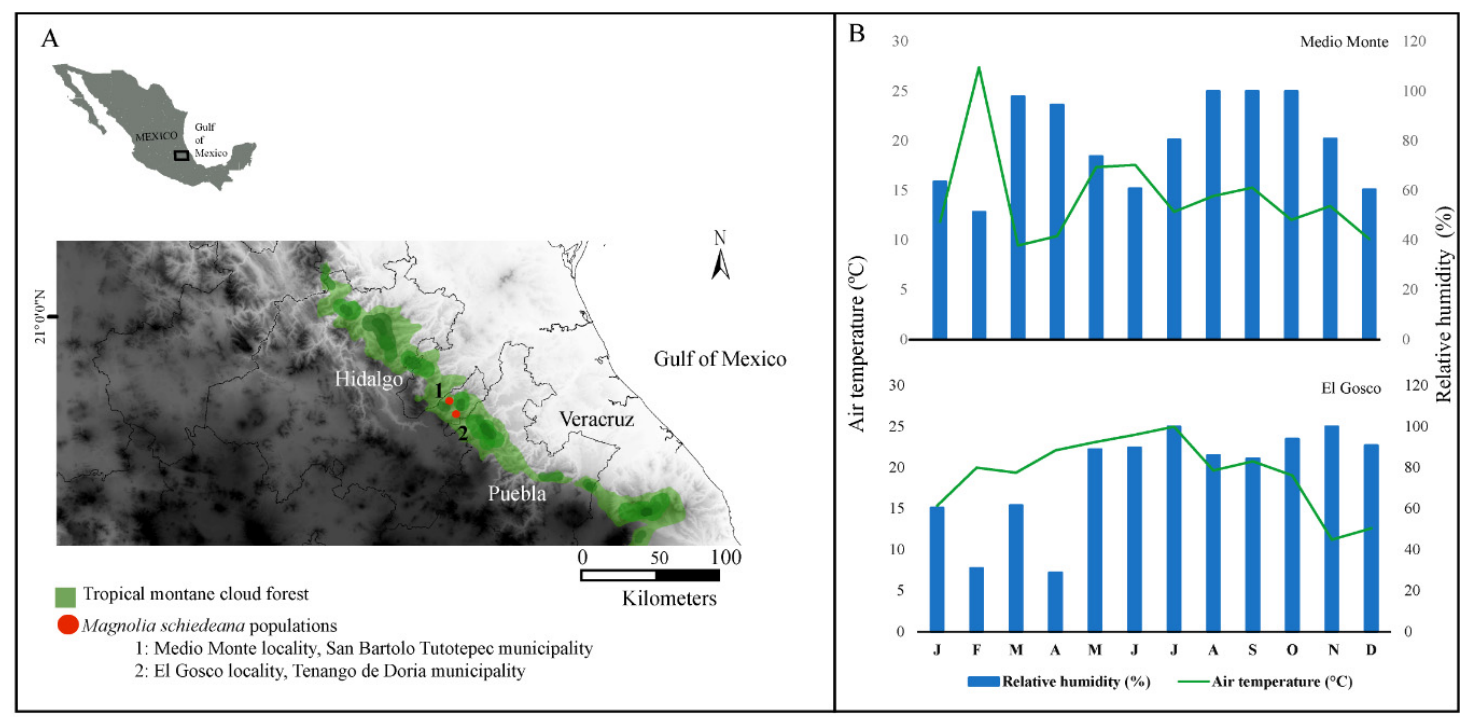

Figure 1. (A) Distribution map of the study forests of the sample Magnolia schiedeana Schltdl. populations across eastern Mexican tropical montane cloud forest (B) climodiagrams from the microclimatic characteristics at data loggers $\left(\mathrm{HOBO}^{\circledR}\right)$, during the year 2019.

In the study area, Magnolia schiedeana coexists with endemic Neotropical montane oaks (e.g., Quercus delgadoana S. Valencia, Nixon and L.M. Kelly, Q. xalapensis Bonpl., Q. germana Schltdl. and Cham., Q. trinitatis Trel., Q. meavei S. Valencia, Sabas and O.J. Soto), Podocarpus reichei J. Buchholz and N.E. Gray, Carpinus caroliniana Walter, Ostrya virginiana (Mill.) K. Koch, Tilia americana var. mexicana (Schltdl.) Hardin, Acer negundo var. mexicanum (DC.) Standl. and Steyerm., Meliosma alba (Schltdl.) Planch., Fagus grandifolia subsp. mexicana (Martínez) A.E. Murray, Liquidambar styraciflua L., Ulmus mexicana (Liebm.) Planch., and several tree fern species [30].

\subsection{Microclimatic Data}

In each study forest, from January to December 2019, one $\mathrm{HOBO}^{\circledR}$ measurement equipment (MX2301 Data Logger, Onset Computer Corporation, Pocasset, Bourne, MA, USA) was set up to record the air temperature $\left({ }^{\circ} \mathrm{C}\right.$ ) and relative humidity $(\% \mathrm{RH})$ at $1 \mathrm{~h}$ intervals (accuracy: $\pm 0.2{ }^{\circ} \mathrm{C}$ and $\pm 2.5 \% \mathrm{RH})$. Mean air temperature $\left({ }^{\circ} \mathrm{C}\right)$ and mean relative humidity $(\%)$ were calculated for each month using $\mathrm{HOBO}$ (Figure 1B).

\subsection{Leaf Sample Collection}

In each study forest, from 10 mature trees per population, we randomly chose 50 fully mature undamaged leaves during March through October 2019. The leaves were selected from the drip area (rooting area) on the ground or from the basal branches of each tree. The distance between individual trees was approximately $10 \mathrm{~m}$, which is far enough to minimize the possibility of sampling related microenvironmental effects to individual trees [31]. After collection, the sample leaves were placed in plastic bags $(10 \times 10 \mathrm{~cm})$ with moist paper towels and placed inside an insulated cooler to avoid any loss of moisture. Leaf samples were transported to the laboratory within 3 days of collecting. Voucher specimens were deposited at the Laboratorio de Biogeografía, Facultad de Ciencias, Universidad Nacional Autónoma de México (UNAM, Mexico).

Leaf Vein Traits

For clearings, 50 fresh leaves of Magnolia schiedeana (previously collected) from each study forest. Fresh Magnolia leaves were immersed in a $50 \%$ solution of $\mathrm{CaO}_{3}$ at $80-90{ }^{\circ} \mathrm{C}$ for $6 \mathrm{~h}$; this removes alcohol-soluble materials such as phenols, silica, and chlorophyll, which are difficult to remove. In general, highly coriaceous leaves are problematic, but satisfactory results can often be obtained by 
increasing the concentration of $\mathrm{CaO}_{3}$ (up to $20 \%$ in extreme cases), and/or increasing the temperature of the oven during the clearing process (up to $85^{\circ} \mathrm{C}$ ) [32]. The best way to clear the leaves of this Magnolia species was by placing them directly into a bleach solution (10\%) for $30 \mathrm{~min}$. We recommend putting them under a dissecting microscope and brushing off hairs with a soft dental brush as much as possible before clearing. After that, we rinsed the leaves three times with tap water, leaving the leaves in a water bath at room temperature for at least $20 \mathrm{~min}$. Once the cleared leaves turned white, we immediately stopped the process by rinsing them three times with tap water (do not allow the water stream to strike the leaf). Finally, each cleared leaf was placed on a paper towel to dry [33,34].

We digitized the 50 Magnolia leaves collected from each study forest; then, we randomly selected 17 digital Magnolia leaf images for Medio Monte and 16 for El Gosco. Each cleared Magnolia leaf was placed directly on the glass of a high-resolution flatbed scanner (HP OfficeJet Pro 7740, Hewlett-Packard Development Company, L.P., Houston, TX, USA). Our leaf samples were scanned at $600 \mathrm{dpi}$. This method allowed us to obtain high-resolution digital images with uniform illumination and minimal sample defects, as the resolution was high enough to zoom in to the finest veins.

For each cleared Magnolia leaf digitalized, we measured seven venation traits: (1) Leaf shape (LS); (2) Vein length (VL); (3) Primary vein size (PVS); (4) Leaf base shape (LBS); (5) Leaf base angle (LBA); (6) Angle between major secondary veins and primary veins (SVPV); and (7) Vein density (VD). Measurement of all leaf vein traits was carried out according to Hickey et al. [34,35] and Zhang et al. [27] (see Figure 2 and Table 1). Fifty measures were performed for each leaf venation traits (accuracy $0.1 \mathrm{~mm}$ ) using image analysis software (ImageJ, http://rsb.info.nih.gov/ij/docs/install/index.html).

Table 1. List of seven Magnolia schiedeana's leaf vein traits with their acronyms and features measured.

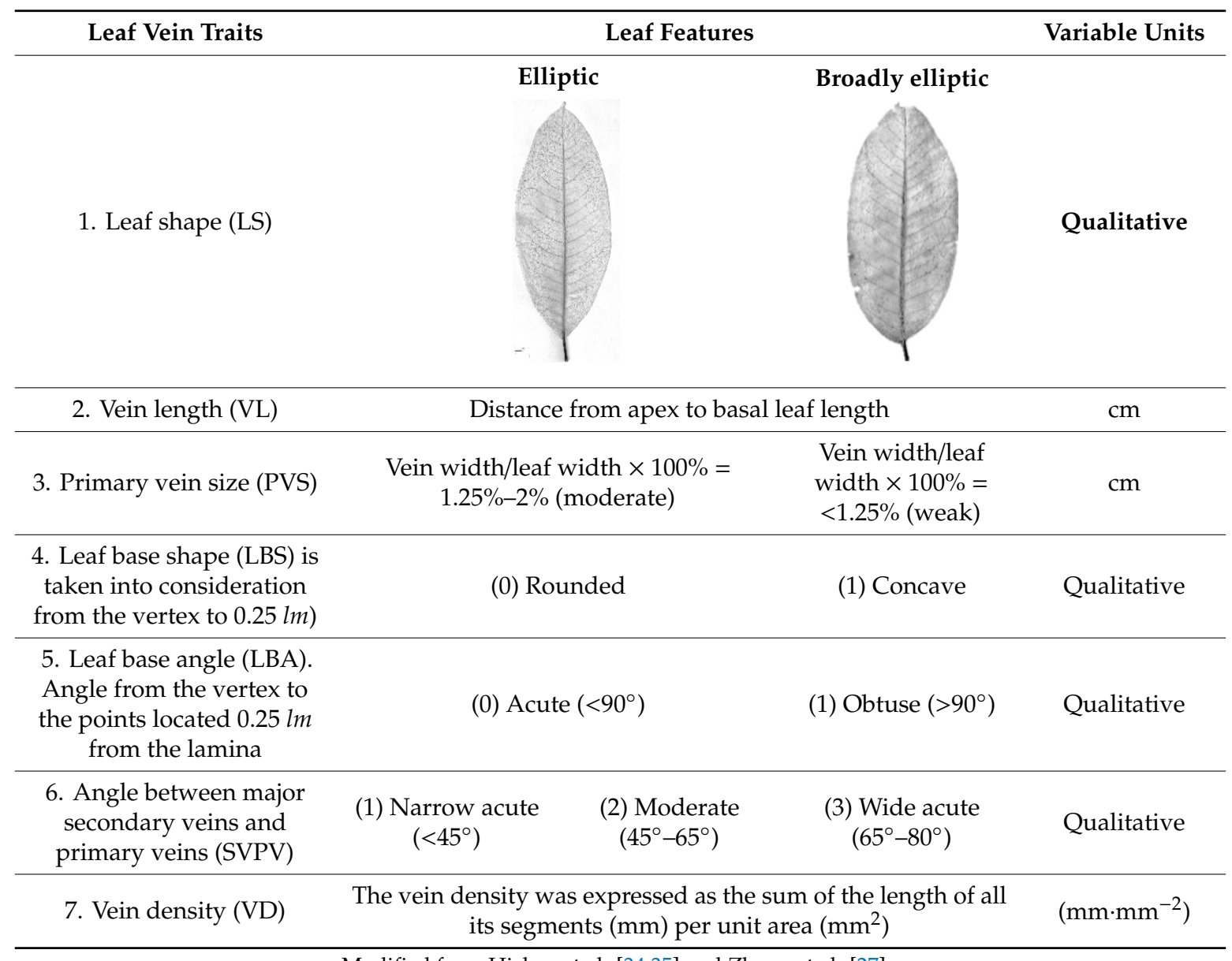




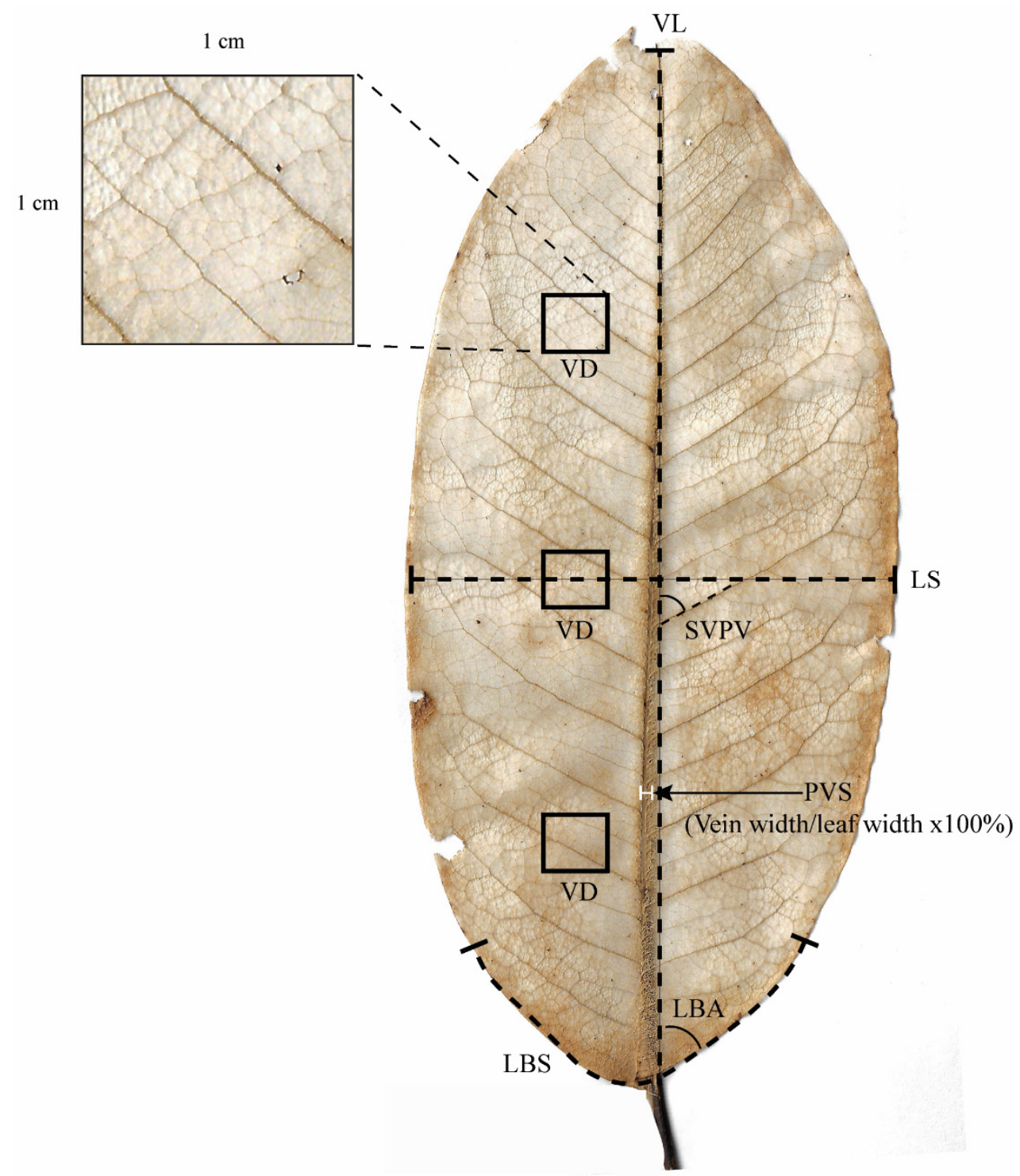

Figure 2. Magnolia schiedeana leaf diagram showing sample vein traits locations. Vein length (VL); Primary vein size (PVS); Leaf base shape (LBS); Leaf base angle (LBA); Angle between major secondary veins and primary veins (SVPV); and Vein density (VD).

\subsection{Microenvironmental Factors}

We randomly selected 10 mature Magnolia tree individuals per population to assess the microenvironmental effect on leaf vein traits of Magnolia schiedeana in two Mexican TMCFs for each Magnolia tree selected (Leaf sample collection section). According to Rodríguez-Ramírez et al. [30], we measured four microenvironmental variables: (1) Litter depth; (2) Soil moisture; (3) Soil temperature; and (4) Canopy openness. The data were measured between 09:00 and 12:00 to standardize the daily microenvironmental fluctuation [31] over an eight-month period (March to October 2019) at two-month intervals. For each Magnolia tree selected, we performed four independent measurements at each of the four cardinal directions using a compass (e.g., north, south, east, and west). The data obtained through the measurements were averaged for statistical analyses.

- Litter depth: was measured by inserting a ruler into the ground until it touched the mineral soil layer.

- Soil moisture: was recorded at a depth of $2-3 \mathrm{~cm}$ using a hygrometer (Lincoln Soil Moisture Meters). This factor took values on a scale from 0 to $100 \%$, where $0=$ dry and $100=$ saturated. 
- Soil temperature: was measured with a soil thermometer (Forestry Suppliers, Taylor ${ }^{\circledR}$ Switchable Digital Pocket Thermometer, Jackson, MS, USA).

- Canopy openness: was estimated in each sample plot using a concave mirror forestry densitometer (Forestry Suppliers, Spherical Crown Densitometers, model A, Jackson, MS, USA).

\section{Statistical Analyses}

We performed a general linear model (GLM) test using binomial (for categorical data) and Gaussian (for count data) distributions [36] to determine whether there was a relationship between leaf vein traits and measured microenvironmental variables for the two Magnolia populations studied. The fit of the microenvironmental variables and leaf vein traits to the binomial and Gaussian distributions were confirmed by the histograms of their frequency distributions $(p<0.05)$. All GLM analyses were analyzed through the "glm2" function in "stats" package, using R version 3.4.3 [37].

\subsection{Dendrochronological Survey}

We sampled 20 Magnolia schiedeana trees from each study site. Dominant trees with a diameter at breast high $(\mathrm{DBH}) \geq 20 \mathrm{~cm}$ were selected to be cored twice at $1.3 \mathrm{~m}$ (breast height) with a increment borer of $5 \mathrm{~mm}$ inner diameter (Häglof ${ }^{\circledR}$, Langsele, Sweden). Individual trees were excluded if they exhibited scars or rot. Each increment borers were filled with treated cork plugs (e.g., treated with a mixture $80 \%$ ethanol and $20 \%$ purified water), which are effective against a broad spectrum of bacteria, fungi, and viruses $[38,39]$.

The wood cores were dried at room temperature, mounted, and polished with successive coarse-grit sandpapers (100 and 360) and four finer-grit sandpapers (400, 600, 1000, 1200, and 2000), until the xylem cellular structure was visible in the transverse section. Wood dust inside vessel lumina was removed with heat by using a hair dryer [13]. The surface as not refilled with white chalk, since the wood was dark enough to increase the contrast of the vessels.

The tree-ring series were dated by assigning calendar years to the rings through the identification of diagnostic growth ring sequences [28]. The annual tree rings of $M$. schiedeana are well-defined by the arrangement of vessels in circular bands in the earlywood and a line of marginal parenchyma in the latewood. We measured the detrended tree-ring width (TRW) using a stereoscopic microscope (Olympus ${ }^{\circledR}$ SZ61, Olympus corporation, Center Valley, PA, USA) and a Velmex tree-ring measuring stage (Velmex, Inc., Bloomfield, NY, USA) with $0.001 \mathrm{~mm}$ accuracy using the TSAP-Win v 4.67c software. Furthermore, we verified the cross-dating with the software COFECHA [40]. The software COFECHA allowed us to identify false rings, missing rings, and cross-dating errors.

To achieve an average TRW, we standardized the raw ring-width series with autoregressive modeling to remove serial correlation using the ARSTAN computer program [41]. We assessed the quality of the chronologies with EPS (expressed population signal) as a measure of the total signal present in the chronology, considering EPS values $>0.85$ [42], the mean correlation coefficient among tree-ring series (Rbar) and a cubic spline with a 50\% response of 30-year periods, which was flexible enough to minimize the non-climatic variance related to climate and/or local variations and maximize high-frequency climatic evidence [43,44].

\subsection{Climate Data}

For each site, we obtained climate data including mean maximum $\left(\mathrm{T}_{\max }\right)$, mean minimum temperature $\left(\mathrm{T}_{\min }\right)$ in ${ }^{\circ} \mathrm{C}$, and monthly precipitation $(\mathrm{P})$ in $\mathrm{mm}$ directly from the CLImate COMputing project (CLICOM database; http://clicom-mex.cicese.mx/), with records dating back to 1942. These climate data were the average values of observation data over 77 years.

To explore the climate sensitivity of Magnolia schiedeana growth, we used Pearson's correlation coefficients as a measure of similarity using SigmaStat v.4 (Systat software, Jandel Scientific, California, CA, USA). The correlations were calculated between the tree-ring chronologies and monthly climate 
data for temperature and monthly precipitation from the previous September (2018) through the current September (2019).

We used the historical drought years (characterized by a low wet season precipitation sum, higher temperatures, and longer dry season) recorded for Mexico (1929-1930, 1940, 1963, 1970, 1972, 1976, 1983, 1991, 1999, 2012, 2015-2016, and 2018-2019) obtained from the Mexican Drought Atlas (http://drought.memphis.edu/MXDA/Default.aspx; [45]). This allowed the recognition of narrow tree rings $(\leq 1.00 \mathrm{~mm})$ in the digital images of wood cores developed before, during, and after a drought event [13].

\subsection{Wood Vessel Traits}

To determine how historical drought years affect the plasticity of vessel traits (density, hydraulic diameter, and percentage of conductive vessel area) of Magnolia schiedeana, we initially randomly selected a subset of 18 digital images of wood cores of each Magnolia population. From both study forests, a total of 36 digital images (previously dated) of wood cores were taken. Each digital image of wood cores was captured using a stereoscopic microscope (Leica Z16 APOA, Leica microsystems, Guadalajara. Mexico) with a 12.9 to $50.3 \mu \mathrm{m}$ field of depth. Images were taken with a digital camera (Leica DFC 490, Leica microsystems, Guadalajara, Mexico) and saved in TIFF format with a $1.3 \mu \mathrm{m}$ per pixel resolution [46].

For each digital image of wood core selected, tree rings were demarcated using the software Adobe Illustrator CC v. 21.0.

Within each digital image of wood cores, vessel traits were measured for the tree-ring width identified before, during, and after each drought event $[13,46]$. We considered vessel density, hydraulic diameter, and percentage of conductive vessel area, because these vessel traits could give a better approximation of the hydric resilience capacity of the diffuse-porous wood of Magnolia species to drought events.

(1) Vessel density (VD) was directly measured ( $\mathrm{mm}$ ) on each digital image of demarcated wood core. The number of vessels per square $\left(\mathrm{mm} \cdot \mathrm{m}^{-2}\right)$ was calculated within the area between two wood rays per each tree-ring.

(2) Hydraulic diameter $\left(\mathrm{D}_{h}\right)$ was calculated $(\mu \mathrm{m})$ according to Sperry and Saliendra [47]: $D_{h}=\sum_{n=1}^{N} d_{n}^{5} / \sum_{n=1}^{N} d_{n}^{4}$, where $\mathrm{d}_{n}$ is the diameter of the $n$ conduit within a tree-ring containing $n$ vessels [48-50].

(3) Percentage of conductive area (PCA) was calculated according to Rodríguez-Ramírez et al. [42]: $P C A=\frac{1}{\frac{X}{Y}+1} \times 100$, where $\frac{X}{Y}=$ ratio of cell wall lumen.

For each digital area between two wood rays and per each tree ring (within each digital image of wood cores), we quantified and manually measured all the vessel traits (VD, $\mathrm{D}_{h}$, and PCA) using the software ImageJ [46,51,52].

We performed an Analysis of Variance (ANOVA) and Tukey multiple comparison or U-Mann-Whitney test depending of the nature of the data to assess whether the values of the vessel traits presented a significant difference between drought years (DY) and non-drought years (NDY) for the Magnolia species studied. These analyses were performed in R software using the R-package ggplot2 [53,54].

\section{Results}

\subsection{Microenvironmental Requirements}

The values of some microenvironmental factors differed significantly between the two Magnolia populations (Figure 3). There was no significant difference in the temperature and canopy openness values between $\mathrm{El} \mathrm{Gosco}$ and Medio Monte localities. In addition, there was no statistically significant difference in soil temperature, $\mathrm{U}=669, \mathrm{~N}=40, p=0.210$ and soil moisture, $t=1.597$, degree freedom $=18$, 
$p=0.128$ ). In contrast, the differences in the canopy openness and litter depth values between the two localities were greater than the expected by chance and hence statistically different (canopy openness, $\mathrm{U}=406, \mathrm{~N}=40, p=<0.001$; litter depth, $\mathrm{t}=3.665, \mathrm{df}=18, p=0.002)$.
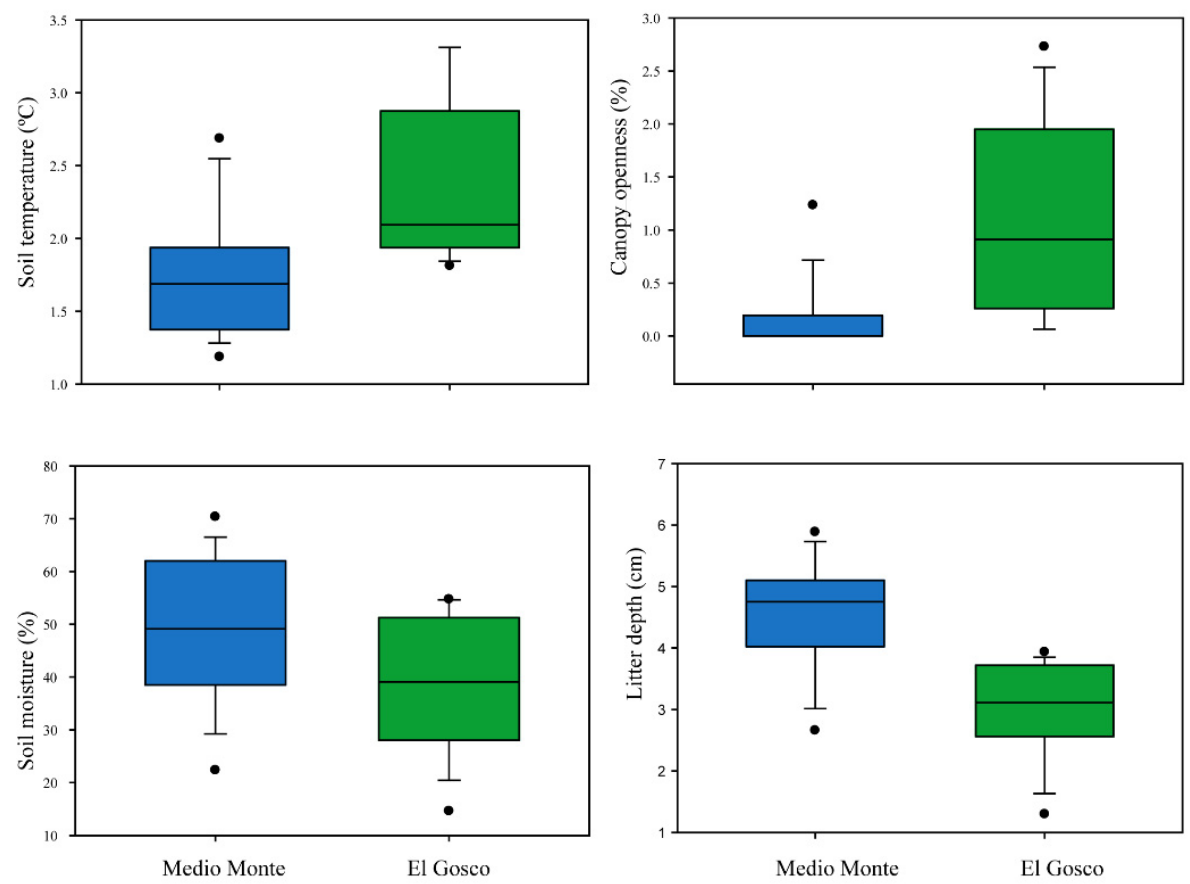

Figure 3. Box plots showing the microenvironmental fluctuations in the study forests of the Hidalgo state. The levels highs and lows in the boxes represent 75th and 25th percentiles, and whiskers represent the 90th and 10th percentiles. The circles show outliers. The solid line represents the arithmetic average and numbers within each box indicate statistically significant differences $(p<0.05)$ between localities.

\subsection{Microenvironmental Effect on Leaf Vein Traits}

All the microenvironmental variables (e.g., litter depth, soil moisture, soil temperature, and canopy openness) significantly affected leaf vein traits (Table 2). The interaction between soil moisture and litter depth significantly influenced LS; high soil moisture and litter depth promoted the presence of elliptical leaves. The VL increased with high soil moisture (Table 2). Additionally, the PVS was influenced by a closed canopy and high litter depth. Leaves with primary vein size $<1.25 \%$ (weak; Table 1 ) occurred at open canopy sites ( 0 to 3 ), while leaves with primary vein size $>1.25$ to $<2 \%$ (moderate; Table 1 ) occurred only in closed canopy sites.

Table 2. Variable coefficients used for the general linear model (GLM) model. Microenvironmental variables influencing the leaf vein traits [Leaf shape (LS); Vein length (VL); Primary vein size (PVS); Leaf base shape (LBS); Leaf base angle (LBA); Angle between major secondary veins and primary veins (SVPV); and Vein density (VD)].

\begin{tabular}{cccccccc}
\hline & LS & VL & PVS & LBS & LBA & SVPV & VD \\
\hline Intercept & 5.58 & 13.84 & 1.08 & -0.77 & 60.49 & 36.02 & 0.47 \\
Soil temperature $\left({ }^{\circ} \mathrm{C}\right)$ & 0.14 & $\mathbf{- 0 . 9 9}$ & 0.24 & $\mathbf{1 . 8 8}$ & 0.04 & $\mathbf{5 . 8 5}$ & $\mathbf{0 . 0 7}$ \\
Canopy openness $(\%)$ & 0.25 & 0.85 & $\mathbf{- 0 . 3 5}$ & 0.3 & -0.63 & -4.02 & $\mathbf{- 0 . 0 6}$ \\
Soil moisture $(\%)$ & $\mathbf{- 0 . 9 5}$ & $\mathbf{1 . 1 7}$ & 0.06 & 0.63 & $\mathbf{1 . 7 9}$ & 0.95 & -0.002 \\
Litter depth $(\mathrm{cm})$ & $\mathbf{- 0 . 6 5}$ & 0.12 & -0.12 & -1.65 & $\mathbf{- 2 . 0 6}$ & -1.35 & -0.05 \\
Akaike information criterion & 29.1 & 95.005 & 39.17 & 24.3 & 127.06 & 124.09 & -33.06 \\
\hline
\end{tabular}

In bold means $p<0.05$ values. 
The interactions between soil moisture-litter depth and LBS and LBA were significant, indicating that leaf base traits of each study forest depended on canopy coverage. Soil temperature was positively related to acute-obtuse leaf bases. Otherwise, leaves with an acute angle were present in environments with low soil temperature. In addition, the angle of the base was inversely related to the litter depth. Finally, the SVPV and VD intensified as the soil temperature increased (Table 2).

\subsection{Tree-Ring Width Chronology}

The longest individual series exceeded 190 years (Table 3), but we considered chronologies reliable beginning in 1847 for Magnolia schiedeana. Likewise, the Magnolia growth rings exhibited a few false rings (less than $0.3 \%$ ) and some micro-rings, which enhanced the mean sensitivity of the species chronology. The independent chronologies spanned up to 191 years for Medio Monte and 172 years for El Gosco (Figure 4). A correlation between the two sites was detected, where the mean sensitivity to climatic variables was high and similar among sites (Table 3). The Rbar values of Medio Monte (0.46) and El Gosco (0.44) and the average EPS of 0.94 indicate that the chronology shows good quality and a strong common signal among trees. Notwithstanding, the differences in performance reflect the differences in the low-frequency properties on the raw data. The average annual radial growth varied from a minimum of $0.91 \mathrm{~mm}$ to a maximum of $1.87 \mathrm{~mm}$ (Medio Monte), and a minimum of $0.97 \mathrm{~mm}$ to a maximum of $1.57 \mathrm{~mm}$ (El Gosco) (Table 3).
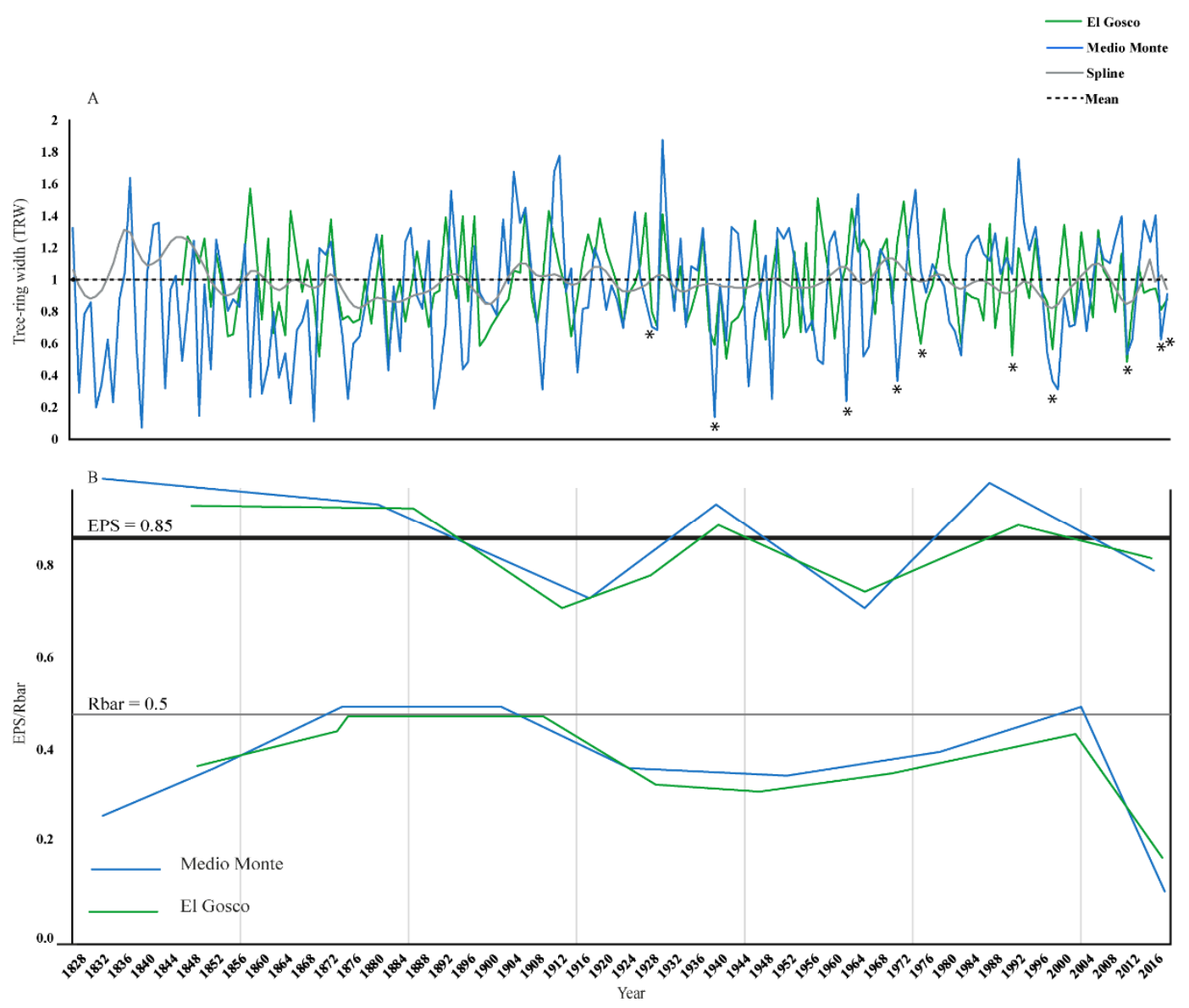

Figure 4. (A) Ring-width chronologies of M. schiedeana from Medio Monte and El Gosco localities. Black asterisks represent the drought events (1929-1930, 1940, 1963, 1970, 1972, 1976, 1983, 1991, 1999, 2012, 2015-2016, and 2018-2019). (B) Expressed population signal (EPS) and effective signal (Rbar) for the two Magnolia schiedeana populations chronologies (Table 3) calculated using a moving window of 30 years. An EPS threshold of 0.85 is depicted in black, and a Rbar threshold of 0.5 is depicted in gray. 
Table 3. Tree-ring characteristics for two Magnolia schiedeana populations.

\begin{tabular}{|c|c|c|}
\hline \multirow[b]{2}{*}{ Statistics } & \multicolumn{2}{|c|}{ Magnolia Populations } \\
\hline & Medio Monte & El Gosco \\
\hline Sampled trees & 20 & 20 \\
\hline Cross-dated series $^{a}$ & 32 & 30 \\
\hline Maximum and minimum age sampled & $190 / 80$ & $172 / 64$ \\
\hline Series intercorrelation $b$ & 0.698 & 0.785 \\
\hline Master series (year) & $1829-2019$ & $1847-2019$ \\
\hline False rings & 3 & 8 \\
\hline Autocorrelation ${ }^{a}$ & 0.632 & 0.587 \\
\hline EPS $^{\mathrm{c}}$ & 0.95 & 0.86 \\
\hline $\operatorname{Rbar}^{\mathrm{C}}$ & 0.46 & 0.44 \\
\hline
\end{tabular}

${ }^{a}$ Values obtained with COFECHA. ${ }^{\mathrm{b}}$ Values statistically different using Mann-Whitney test $(p=0.05) .{ }^{\mathrm{c}}$ Values obtained with ARSTAN.

The similarity in growth patterns of Magnolia trees within each site was consistently high; notwithstanding, decreased radial growth was associated with several historical drought events (e.g., 1929-1930, 1940, 1963, 1970, 1972, 1976, 1983, 1991, 1999, 2012, 2015-2016, and 2018-2019; Figure 4).

\subsection{Tree Growth-Climate Relationship}

The climate-growth analysis over the common period from 1941 to 2016 indicated that Magnolia schiedeana growth was strongly related to summer conditions (Figure 5). The growth responses to $\mathrm{T}_{\max }, \mathrm{T}_{\min }$, and precipitation were similar. Both sites have a significant positive correlation with precipitation from June to September in summer, with coefficient values also above $0.3(p<0.05)$, which represents the strongest climate signal obtained in the results, implying that smaller rings are formed during drier conditions.

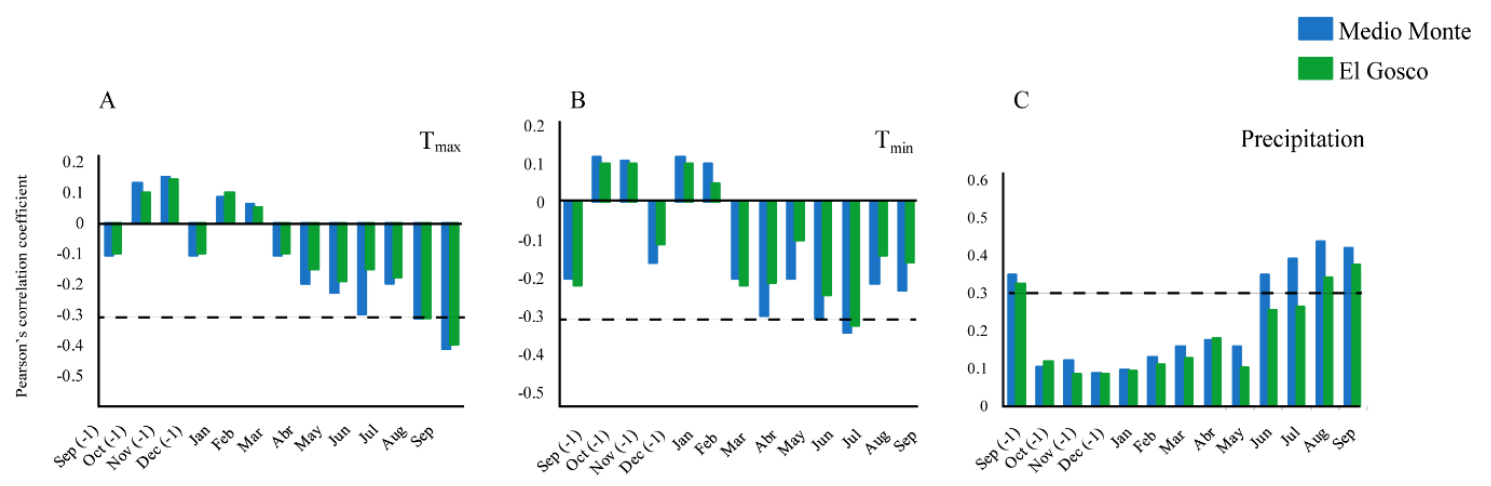

Figure 5. Correlations between chronologies against the mean maximum temperature (A), mean minimum temperature (B) and monthly precipitation (C) for each drought year (DY) (September ( -1$)$ to September) from the year 1941 onward. Horizontal dashed lines indicate the significance intervals $(p<0.05)$ for correlation coefficients. $(-1)$ show the previous years and $(+1)$ the following years in which growth started.

The composite chronology showed a positive but non-significant relation with $\mathrm{T}_{\max }$ and $\mathrm{T}_{\min }$ in the early growing season and a significant negative relationship with mean summer temperature (Figure 5). Summer to early autumn 2019 (June, July, August, and September) correlated significantly and negatively with all Magnolia trees. Additionally, spring and early summer 2019 (March, April, May, and June) and late summer 2019 (July, August, and September) were important for radial growth; $T_{\max }$ and $T_{\min }$ correlated significantly and negative, indicating the strongest and weakest association, respectively. $T_{\max }$ and $T_{\min }$ during October through November 2018 as well as January through February 2019 had a positive relationship with radial growth in the two Magnolia populations studied (Figure 5). 


\subsection{The Effect of Drought Events on Vessel Traits}

A total of 8000 vessels were measured directly from the selected digital images of wood cores (see Digitalization of wood cores section). On average, an annual ring included 17 (for El Gosco) and 20 (for Medio Monte) xylem vessels in both Magnolia populations studied. Clear differences were found at both sites: vessel density per square $\mathrm{mm}$ in non-drought years (NDY) were larger than those identified in drought events (DY) (Figure 6A). Hydraulic diameter $(\mu \mathrm{m})$ was similar in the two Magnolia populations studied (Medio Monte, ranges from 1-40 for DY and 10-140 in NDY; and El Gosco, ranges from 1-38 for DY and 8-137; Figure 6B). Finally, a similar range of variation was found between populations for the percentage of conductivity area in DY and NDY (Figure 6C). Vessel traits showed evidence of temporal fluctuations at both sites.
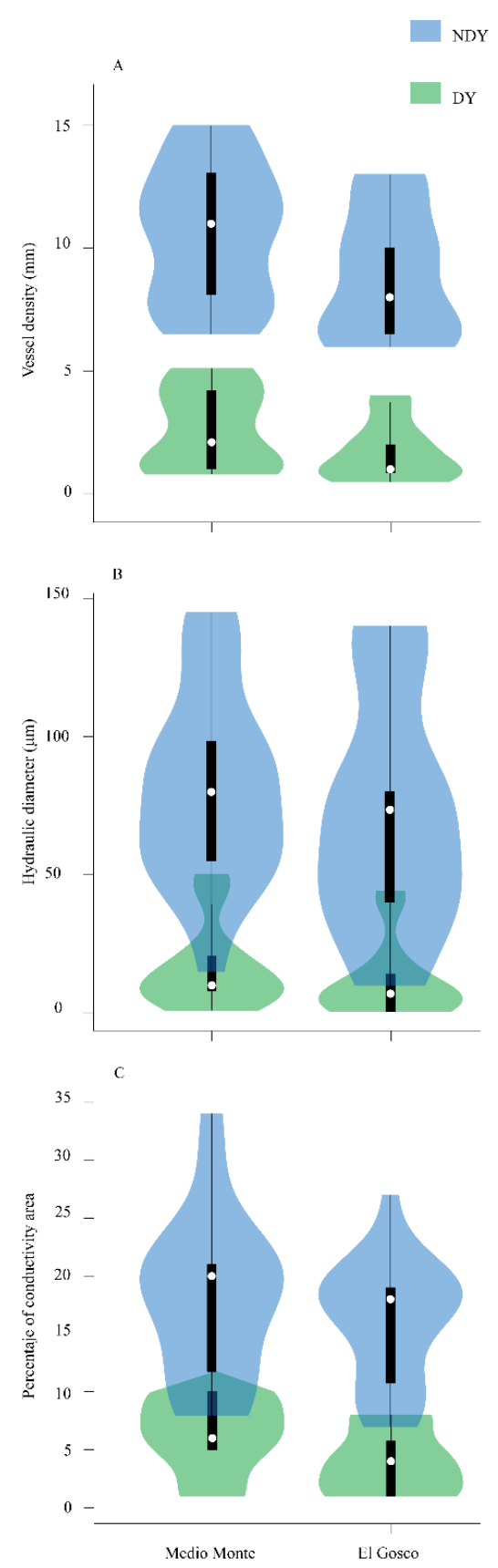

Figure 6. Violin plots showing differences in vessel traits between drought years (DY) and non-drought years (NDY) for both Magnolia schiedeana populations studied. (A) VD; (B) hydraulic diameter $\left(\mathrm{D}_{h}\right)$ and (C) percentage of conductive area (PCA). 


\section{Discussion}

Forest canopy closure dictates local climate through the effects on microenvironmental factors. Mexican beech forests exhibit dense canopies that provide lower ground-layer air temperatures and increased relative humidity and shade in the understory [30,55]. Hence, the decrease in canopy openness of trees in the TMCFs affects the local microenvironmental factors caused by forest canopy closure [56]. The frequent occurrence of Magnolia schiedeana in Mexican beech forests could indicate a historical dependency on the specific microenvironmental conditions [46] that allow older species such as Magnolia to survive long periods of time ( $>300$ years). New lineages would be generated in the face of large-scale climate fluctuations, whereas intermediate levels of disturbance at local to regional scales would maximize genetic diversity [20]. Fog and mist in Mexican beech forests can also protect mid-canopy tree species from summer drought, increasing resilience and thus buffering the climate impact $[23,44]$. Nevertheless, the microenvironmental differences found among Magnolia populations (Figure 3) could be a consequence of habitat fragmentation and thus represent critical factors or opportunities to ensure future conservation efforts of the TMCF tree species [1,57].

In Mexican beech forest, canopy closure decreased warming in the mid-canopy (where Magnolia schiedeana is typically found) and the understory [30]. Atmospheric temperatures provided an unrealistic benchmark against which to compare microenvironmental fluctuations. Hence, the relationship between the architecture of leaf vascular networks and microenvironmental factors could partially explain climate adaptation within Magnolia populations [58-61], which may allow local persistence and response linked to local climate fluctuations [14,62].

\subsection{Leaf Venation as Evidence to Microenvironmental Adaptation}

The relationship between microenvironment and leaf vein traits effects upon final leaf morphology have important implications for microclimatic research. Magnolia schiedeana is resilient to seasonal climate fluctuations and heat waves during summer (from April to June). Likewise, M. schiedeana keeps all its leaves for 60 months [63]. However, late drought events can significantly affect the morphology of leaves and growth of trees $[11,28,62]$.

We have demonstrated a strong microenvironmental effect (high soil moisture and litter depth) on variations in Leaf shape (LS) and Vein length (VL) presence. According to Givnish [58] and Sack [64], the leaf shape is related to local climate conditions, where elliptic leaves are common in TMCFs and broadly elliptic leaves are frequent in relatively dry but shady ecosystems. Medio Monte exhibited elliptic leaves and El Gosco exhibited mostly broadly elliptic leaves. The differences found between microenvironmental factors, LS and VL (Table 2) among study forests, can be attributed to the degree of forest fragmentation of each Mexican beech study site as previously mentioned by Rodríguez-Ramírez et al. [65].

Likewise, primary vein size (PVS) fluctuated among sites [Medio Monte $>1.25$ to $<2 \%$ (moderate) and El Gosco $<1.25 \%$ (weak)]; these dissimilarities could indicate a morphological shift consistent with a direct response to canopy openness and litter depth variations [14,62]. Concerning Leaf base angle (LBA) and Leaf base shape (LBS), the soil moisture and litter depth were key in the presence of acute-obtuse leaf bases [58,59] among study forests. Several tree species have a demonstrated a capacity to adjust the PVS, LBS, and LBA in leaves produced in exposed versus shaded habitats, and from the bottom to top of the canopy [64]; in general, it appears that in many clades of land plants, the PVS topology is conservative and slow evolving [11,66]. Sack et al. [64] demonstrated that broader leaves are more susceptible to extreme temperature, such as those at El Gosco (LS = broadly elliptic; PVS $<1.25 \%$ weak; LBA $=$ acute $<90^{\circ}$ ). Our study indicates that high soil temperature effects the architecture of Angle between major secondary veins and primary veins (SVPV) and Vein density (VD). This is most likely because Magnolia schiedeana represents a TMCF tree species, which benefits from high soil moisture and thus is somewhat buffered against changes in rainfall rates (Table 2). 
We confirm leaf vein traits as a new tool to interpret microenvironmental effects at a fine-scale as suggested by Blonder et al. [59] and Zhang et al. [27]. When Mexican beech forests modify their local microenvironmental factors (e.g., litter depth, soil moisture, soil temperature, canopy openness, $\mathrm{pH}$, among others), these directly influence mid-canopy and understory characteristics (the habitat of Magnolia schiedeana). This approach provides quantitative evidence for the $M$. schiedeana's leaf vein traits and specific microenvironmental factors. However, heat waves often occur in late April to early June (Figure 1B); this can upset the growth of trees and the development of new leaves, which plays a key role in hydric adaptations to drought caused by prolonged rainfall deficits.

\subsection{Wood Anatomy as Evidence to Climate Adaptation}

Our results show that $M$. schiedeana develops annual growth rings that can be used in wood anatomy and xylogenesis studies and are relevant to assess the plasticity of vessel-related drought events. Similar to M. vovidesii A. Vázquez, Domínguez-Yescas and L. Carvajal [23], Magnolia hypoleuca Siebold \& Zucc. [67] and M. acuminata (L.) L. [68]. These results are reinforced by the observations of Mexican beech trees $[13,28]$.

The presence of Magnolia trees with maximum ages of 172-190 years old (Figure 4) allowed us to assess the effects of climate on growth by comparing tree rings to weather station data back to the year 1942. A robust common signal throughout the chronologies in noted by comparing the mean Rbar statistics of Magnolia schiedeana chronologies from Medio Monte (0.46) and El Gosco (0.44) localities that possess relatively high EPS values varying from 0.86 to 0.95 (above the 0.85 threshold) (Table 3).

In this study, Magnolia schiedeana TRWs were correlated to $\mathrm{T}_{\max }$ from May through September and negatively influenced growth rates that start in February (Figure 5A). According to Rodríguez-Ramírez et al. [46], the maximum growth rate occurs in autumn (August-September) but rapidly decreases in late autumn to early winter (November and December). This is consistent with the correlation with $\mathrm{T}_{\min }$ with current June and July (Figure 5B). Possibly, the fog/mist and canopy closure effects might play a key role during heat waves events [5], resulting in narrow rings and the leaf vein traits adaptations, during and after drought events [23]. The observed Magnolia growth was also negatively correlated with maximal temperatures from June to August, despite the absence of continuous precipitation during late December and January (winter), which affects the annual growth.

Likewise, we found that Magnolia schiedeana was most sensitive to precipitation (previous September, current June to current September; Figure 5C), with more pronounced interannual growth rate variations than Mexican beech [28]. Our results support the suggestions of Rodríguez-Ramírez et al. [46] and Takahashi and Okuhara [67] in the sense that local climate fluctuations have a large effect on the growth of Magnolia species. We believe that specific Mexican beech forests' climatic factors are influencing Magnolia's TRWs allowing them to adapt to drought events.

In addition, including the vessel traits analyzed (density, hydraulic diameter, and percentage of conductivity area) in Magnolia schiedeana may accurately link wood anatomy and leaf vein response to climatic oscillations. Variability in vessel traits were found to be mainly related to specific extreme climatic fluctuations, such as the extreme El Niño-Southern Oscillation (ENSO) events in 1929-1930, 1940, 1963, 1970, 1972, 1976, 1983, 1991, 1999, 2012, 2015-2016, and 2018-2019. These climate oscillations were usually recorded in growth rings (Figure 4) and provide a wider range of climatic data. Nevertheless, vessel traits have rarely been applied to intra-seasonal climate variability $[46,69]$. Vessel plasticity architecture plays an essential role in water transport [70] and adjusting the wood anatomy through tree physiological modifications to climatic resilience [48]. As reported by Rodríguez-Ramírez et al. [13,46], Fagus grandifolia subsp. mexicana (Martínez) A.E. Murray and Magnolia spp. develop functional plasticity of vessel anatomy to climatic variability, which may indicate that several TMCF trees may also adapt to climatic oscillations.

In addition, including the vessel traits (density, hydraulic diameter, and percentage of conductivity area) in our study, we can say that wood anatomy, as well as leaf vein responded to climatic oscillations in Magnolia schiedeana. Our results suggest that M. schiedeana's wood vessels showed a 
high plasticity of growth rings development during drought years (DY) and non-drought years (NDY) (Figure 6). Variation in Vein density (VD), Hydraulic diameter (Dh) and Percentage of conductivity area (PCA) in tree-ring width between DY and NDY in Magnolia schiedeana indicate a climatic adaptation corroborating the high plasticity already recorded in other Magnolia species $[23,46]$. We found that VD, $\mathrm{D}_{h}$, and PCA values were lower in El Gosco than Medio Monte (Figure 6A-C), implying a sheltering from drought events. For instance, Medio Monte locality, having less of an anthropogenic influence and the more favorable climatic conditions (high fog and/mist rates), exhibited a wider adaptability of hydraulic adjustment than El Gosco. The Medio Monte locality, being better preserved, may influence M. schiedeana adaptation to specific microclimatic conditions and allow individuals to face climatic fluctuations. In contrast, the El Gosco locality is a severely fragmented habitat, resulting in greater plasticity of vessel hydraulic architecture.

Understanding the specific wood anatomical responses and elucidation of the vessel traits could contribute to a better understanding of the plasticity in vessel hydraulic architecture and the different strategies adopted by M. schiedeana when it is exposed to changing climate fluctuations. Regrettably, Rodríguez-Ramírez et al. [46] suggest that the specific microenvironmental conditions depend on the specific habitats that Mexican beech forests occupy. This suggests that populations of M. schiedeana may be less resilient to increasing temperature and hydric stress in the future.

\section{Conclusions}

This study provides the first evidence linking that leaf vein traits and wood anatomy plasticity in populations of Magnolia schiedeana respond to microenvironmental and climate fluctuations. Leaf vein traits were more sensitive to microenvironmental variations, whereas wood anatomy (e.g., tree-ring width, and vessel traits) were more sensitive to regional climate variations. Magnolia schiedeana habitat not only depends on rainfall, fog/mist, and drizzle, but also plays a critical role in in the structure and composition of Mexican beech forests that it occupies [23,46]. Future dendroecological studies on tropical montane cloud forest trees should focus on the relationship between leaf vascular architecture networks and wood anatomy feature, and how these could be explained by climatic variables.

Author Contributions: E.C.R.-R. designed the experiment; E.C.R.-R. and J.A.V.-N. carried out the data analyses; E.C.R.-R. and I.L.-V. wrote the different drafts of the manuscript; E.C.R.-R., J.A.V.-G., G.D. and I.L.-V. revised all the project stages. All authors have read and agreed to the published version of the manuscript.

Funding: This research was funded by the DGAPA PAPIIT IN223218 project "Evaluando la vulnerabilidad ecológica de especies arbóreas relicto/diagnósticas del bosque templado húmedo del este de México".

Acknowledgments: The first author acknowledges the financial support granted by the postdoctoral fellowship CONACYT 2019-2020. Authors are very grateful to three anonymous reviewers for valuable comments provided.

Conflicts of Interest: The authors declare that they have no conflict of interest.

\section{References}

1. Vázquez-García, J.A. Cloud forest archipelagos: Preservation of fragmented montane ecosystems in tropical America. In Tropical Montane Cloud Forests; Hamilton, L.S., Juvik, J.O., Scatena, F.N., Eds.; Springer: New York, NY, USA, 1995; Volume 110, pp. 296-300. ISBN 9789896540821.

2. Gauthier, S.; Bernier, P.; Burton, P.J.; Edwards, J.; Isaac, K.; Isabel, N.; Jayen, K.; le Goff, H.; Nelson, E.A. Climate change vulnerability and adaptation in the managed Canadian boreal forest. Environ. Rev. 2014, 22, 256-285. [CrossRef]

3. Bruijnzeel, L.A.; Mulligan, M.; Scatena, F.N. Hydrometeorology of Tropical Montane Cloud Forests: Emerging Patterns; Cambridge University Press: Cambridge, UK, 2011; Volume 25, ISBN 9780521760355.

4. Rahbek, C.; Borregaard, M.K.; Antonelli, A.; Colwell, R.K.; Holt, B.G.; Nogues-Bravo, D.; Rasmussen, C.M.Ø.; Richardson, K.; Rosing, M.T.; Whittaker, R.J.; et al. Building mountain biodiversity: Geological and evolutionary processes. Science 2019, 365, 1114-1119. [CrossRef] 
5. Goldsmith, G.R.; Matzke, N.J.; Dawson, T.E. The incidence and implications of clouds for cloud forest plant water relations. Ecol. Lett. 2013, 16, 307-314. [CrossRef] [PubMed]

6. Aldrich, M.; Billington, C.; Edwards, M.; Laidlaw, R. Tropical montane cloud forests: An urgent priority for conservation. WCMC Biodivers. Bull. 1997, 2, 17.

7. Pouteau, R.; Giambelluca, T.W.; Ah-Peng, C.; Meyer, J.Y. Will climate change shift the lower ecotone of tropical montane cloud forests upwards on islands? J. Biogeogr. 2018, 45, 1326-1333. [CrossRef]

8. Gupta, A. The physiology of plant responses to drought. Science 2020, 269, 266-269. [CrossRef] [PubMed]

9. Griggs, D.J.; Noguer, M. Climate change 2001: The scientific basis. Contribution of working group I to the third assessment report of the intergovernmental panel on climate change. Weather 2002, 57, 267-269. [CrossRef]

10. Ponce-Reyes, R.; Reynoso-Rosales, V.H.; Watson, J.E.M.; Vanderwal, J.; Fuller, R.A.; Pressey, R.L.; Possingham, H.P. Vulnerability of cloud forest reserves in Mexico to climate change. Nat. Clim. Change 2012, 2, 448-452. [CrossRef]

11. Blackman, C.J.; Brodribb, T.J.; Jordan, G.J. Leaf hydraulic vulnerability is related to conduit dimensions and drought resistance across a diverse range of woody angiosperms. New Phytol. 2010, 188, 1113-1123. [CrossRef]

12. Scoffoni, C.; Rawls, M.; Mckown, A.; Cochard, H.; Sack, L. Decline of leaf hydraulic conductance with dehydration: Relationship to leaf size and venation architecture. Plant. Physiol. 2011, 156, 832-843. [CrossRef]

13. Rodríguez-Ramírez, E.C.; Terrazas, T.; Luna-Vega, I. The influence of climate on the masting behavior of Mexican beech: Growth rings and xylem anatomy. Trees Struct. Funct. 2019, 33, 23-35. [CrossRef]

14. Wright, I.J.; Dong, N.; Maire, V.; Prentice, I.C.; Westoby, M.; Díaz, S.; Gallagher, R.V.; Jacobs, B.F.; Kooyman, R.; Law, E.A.; et al. Global climatic drivers of leaf size. Science 2017, 357, 917-921. [CrossRef] [PubMed]

15. Gual-Díaz, M.; Rendón-Correa, A. (Eds.) Bosques mesófilos de montaña de México diversidad, ecología y manejo. In Bosques Mesófilos de Montaña de México Diversidad, Ecología y Manejo; CONABIO: Mexico City, Mexico, 2014; pp. 27-67. ISBN 978-607-8328-07-9.

16. Barradas, V.L.; Luis, J.; Cervantes, J. Implicaciones del cambio climático en la fisiología ecológica de las plantas. In Cambio Climático: Aproximaciones para el Estudio de su Efecto sobre la Biodiversidad; Sánchez-Rojas, G., Barrera, C.B., Pavón, N.P., Eds.; Universidad Autónoma del Estado de Hidalgo: Pachuca de Soto, Mexico, 2011; pp. 71-78.

17. Rivers, M.; Beech, E.; Murphy, L.; Oldfield, S. (Eds.) The Red List of Magnoliaceae-Revised and Extended, 1st ed.; Botanic Gardens Conservation International: Richmond, UK, 2016; ISBN 9781905164646.

18. González-Espinosa, M.; Meave, J.A.; Lorea-Hernández, F.G.; Ibarra-Manríquez, G.; Newton, A.C. (Eds.) The Red List of Mexican Cloud Forest Trees, 1st ed.; Fauna \& Flora International: Cambridge, UK, 2011; ISBN 9781903703281.

19. Vásquez-Morales, S.G.; Téllez-Valdés, O.; del Rosario Pineda-López, M.; Sánchez-Velásquez, L.R.; Flores-Estevez, N.; Viveros-Viveros, H. Effect of climate change on the distribution of Magnolia schiedeana: A threatened species. Bot. Sci. 2014, 92, 575. [CrossRef]

20. Vázquez-García, J.A. Magnolia (Magnoliaceae) in Mexico and Central America: A Synopsis. Brittonia 1994, 46, 1. [CrossRef]

21. García-González, I.; Fonti, P. Selecting earlywood vessels to maximize their environmental signal. Tree Physiol. 2006, 26, 1289-1296. [CrossRef]

22. Ariya, U.; Hamano, K.-Y.; Makimoto, T.; Kinoshita, S.; Akaji, Y.; Miyazaki, Y.; Hirobe, M.; Sakamoto, K. Temporal and spatial dynamics of an old-growth beech forest in western Japan. J. For. Res. 2015, 21, 73-83. [CrossRef]

23. Rodríguez-Ramírez, E.C.; Luna-Vega, I. Dendroecology as a research tool to investigate climate change resilience on Magnolia vovidesii, a threatened Mexican cloud forest tree species of eastern Mexico. In Latin American Dendroecology: Combining Tree-Ring Sciences and Ecology in a Megadiverse Territory; Pompa-García, M., Camarero, J.J., Eds.; Springer International Publishing: Cham, Switzerland, 2020; pp. 3-20.

24. Anderegg, W.R.L. Spatial and temporal variation in plant hydraulic traits and their relevance for climate change impacts on vegetation. New Phytol. 2015, 205, 1008-1014. [CrossRef] 
25. Anderegg, W.R.L.; Meinzer, F.C. Wood anatomy and plant hydraulics in a changing climate. In Functional and Ecological Xylem Anatomy; Springer International Publishing: Cham, Switzerland, 2015; pp. 235-253. ISBN 9783319157832.

26. Kawai, K.; Okada, N. Leaf vascular architecture in temperate dicotyledons: Correlations and link to functional traits. Planta 2020, 251, 1-12. [CrossRef]

27. Zhang, L.; Yang, J.; Huang, Y.; Jia, Z.; Fang, Y. Leaf venation variation and phenotypic plasticity in response to environmental heterogeneity in Parrotia subaequalis (H. T. Chang) R. M. Hao et H. T. Wei, an endemic and endangered tree species from China. Forests 2018, 9, 247. [CrossRef]

28. Rodríguez-Ramírez, E.C.; Luna-Vega, I.; Rozas, V. Tree-ring research of Mexican beech (Fagus grandifolia subsp. mexicana) a relict tree endemic to eastern Mexico. Tree-Ring Res. 2018, 74, 94-107. [CrossRef]

29. Peel, M.C.; Finlayson, B.L.; McMahon, T.A. Updated world map of the Köppen-Geiger climate classification. Hydrol. Earth Syst. Sci. 2007, 11, 1633-1644. [CrossRef]

30. Rodríguez-Ramírez, E.C.; Sánchez-González, A.; Ángeles-Pérez, G. Relationship between vegetation structure and microenvironment in Fagus grandifolia subsp. mexicana forest relicts in Mexico. J. Plant. Ecol. 2018, 11, 237-247. [CrossRef]

31. Roberts-Pichette, P.; Gillespie, L. Terrestrial Vegetation Biodiversity Monitoring Protocols; Canada Centre for Inland Waters: Burlington, ON, Canada, 1999.

32. Shobe, R.W.R.; Lersten, N.R. A technique for clearing and staining gymnosperm leaves. Bot. Gaz. 1967, 128, 150-152. [CrossRef]

33. Vasco, A.; Thadeo, M.; Conover, M.; Daly, D.C. Preparation of samples for leaf architecture studies, a method for mounting cleared leaves. Appl. Plant. Sci. 2014, 2, 1400038. [CrossRef]

34. Ash, A.; Ellis, B.; Hickey, L.J.; Johnson, K.; Wilf, P.; Wing, S. (Eds.) Manual of Leaf Architecture-Morphological Description and Categorization of Dicotyledonous and Net-Veined Monocotyledonous Angiosperms, 1st ed.; Smithsonian Institution: Washington, DC, USA, 1999; ISBN 0967755409.

35. Hickey, L.J. Classification of the architecture of dicotyledonous leaves. Am. J. Bot. 1973, 60, 17. [CrossRef]

36. Zeileis, A.; Hornik, K. Generalized M-fluctuation tests for parameter instability. Stat. Neerl. 2007, 61, 488-508. [CrossRef]

37. Package 'glm2,'. Available online: http://mirror.psu.ac.th/pub/cran/web/packages/glm2/glm2.pdf (accessed on 20 March 2020).

38. Polge, H.; Thiercelin, F. Dégâts occasionnés par les sondages à la tarière. Rev. For. Française 1970, 461, 629-636. [CrossRef]

39. Thiercelin, F.; Arnould, M.-F.; Mangenot, F.; Polge, H. Altérations du bois provoquées par les sondages à la tarière. Leur contrôle. Ann. Des. Sci. For. 1972, 29, 107-133. [CrossRef]

40. Grissino-Mayer, H.D. Evaluating crossdating accuracy: A manual and tutorial for the computer program COFECHA. Tree-Ring Res. 2001, 57, 205-221.

41. Cook, E.R.; Holmes, R.L. Guide for computer program ARSTAN. In The International Tree-Ring Data Bank Program Library Version 2.0 User's Manual; Grissino-Mayer, H.D., Holmes, R.L., Fritts, H.C., Eds.; Laboratory of Tree-Ring Research: Tucson, AZ, USA, 1996; pp. 75-87.

42. Briffa, K.R. Interpreting high-resolution proxy climate data-The example of dendroclimatology. In Analysis of Climate Variability; von Storch., H., Navarra, A., Eds.; Springer: Berlin/Heidelberg, Germany, 1999; Volume 0500, pp. 77-94.

43. Gareca, E.E.; Fernández, M.; Stanton, S. Dendrochronological investigation of the high Andean tree species Polylepis besseri and implications for management and conservation. Biodivers. Conserv. 2010, 19, 1839-1851. [CrossRef]

44. Dittmar, C.; Elling, W. Dendroecological investigation of the vitality of common beech (Fagus sylvatica L.) in mixed mountain forests of the Northern Alps (South Bavaria). Dendrochronologia 2007, 25, 37-56. [CrossRef]

45. Stahle, D.W.; Cook, E.R.; Burnette, D.J.; Villanueva, J.; Cerano, J.; Burns, J.N.; Griffin, D.; Cook, B.I.; Acuña, R.; Torbenson, M.C.A.; et al. The Mexican drought Atlas: Tree-ring reconstructions of the soil moisture balance during the late pre-Hispanic, colonial, and modern eras. Quat. Sci. Rev. 2016, 149, 34-60. [CrossRef]

46. Rodríguez-Ramírez, E.C.; Vázquez-García, J.A.; García-González, I.; Alcántara-Ayala, O.; Luna-Vega, I. Drought effects on the plasticity in vessel traits of two endemic magnolia species in the tropical montane cloud forests of eastern Mexico. J. Plant. Ecol. 2020, 13, 331-340. [CrossRef] 
47. Sperry, J.S.; Saiendra, N.Z. Intra- and inter-plant variation in xylem cavitation in Betula Occident. Plant Cell Environ. 1994, 17, 1233-1241. [CrossRef]

48. García-González, I.; Souto-Herrero, M.; Campelo, F. Ring-porosity and earlywood vessels: A review on extracting environmental information through time. IAWA J. 2016, 37, 295-314. [CrossRef]

49. Souto-Herrero, M.; Rozas, V.; García-González, I. A 481-year chronology of oak earlywood vessels as an age-independent climatic proxy in NW Iberia. Glob. Planet. Change 2017, 155, 20-28. [CrossRef]

50. Camarero, J.J. Linking functional traits and climate-growth relationships in Mediterranean species through wood density. IAWA J. 2019, 40, 215-240. [CrossRef]

51. Souto-Herrero, M.; Rozas, V.; García-González, I. Earlywood vessels and latewood width explain the role of climate on wood formation of Quercus pyrenaica Willd. across the Atlantic-Mediterranean boundary in NW Iberia. For. Ecol. Manag. 2018, 425, 126-137. [CrossRef]

52. Schneider, C.A.; Rasband, W.S.; Eliceiri, K.W. NIH Image to ImageJ: 25 years of image analysis. Nat. Methods 2012, 9, 671-675. [CrossRef]

53. Hintze, J.L.; Nelson, R.D. Violin plots: A box plot-density trace synergism. Am. Stat. 1998, 52, 181-184.

54. Wickham, H. ggplot2: Elegant Graphics for Data Analysis, 2nd ed.; Gentleman, R., Hornik, K., Parmigiani, G., Eds.; Springer: Houston, TX, USA, 2016; Volume 35, ISBN 978-0-387-98140-6.

55. Rodríguez-Ramírez, E.C.; Martínez-Falcón, A.P.; Luna-Vega, I. Spatial patterns of Mexican beech seedlings (Fagus grandifolia subsp. mexicana (Martínez) A.E. Murray): Influence of canopy openness and conspecific trees on recruitment mechanisms. Ann. For. Sci. 2018. [CrossRef]

56. Williams-Linera, G.; Tolome, J. Litterfall, temperate and tropical dominant trees, and climate in a Mexican lower montane forest. Biotropica 1996, 28, 649-656. [CrossRef]

57. Jiménez-García, D.; Peterson, A.T. Climate change impact on endangered cloud forest tree species in Mexico. Rev. Mex. de Biodivers. 2019. [CrossRef]

58. Givnish, T.J. Leaf and canopy adaptations in tropical forests. In Physiological Ecology of Plants of the Wet Tropics; Medina, E., Mooney, H.A., Vazquez-Yanes, C., Eds.; Springer: Mexico City, Mexico, 1984; pp. 51-84.

59. Blonder, B.; Kapas, R.E.; Dalton, R.M.; Graae, B.J.; Heiling, J.M.; Opedal, Ø.H. Microenvironment and functional-trait context dependence predict alpine plant community dynamics. J. Ecol. 2018, 106, 1323-1337. [CrossRef]

60. Vergara-Gómez, D.; Williams-Linera, G.; Casanoves, F. Leaf functional traits vary within and across tree species in tropical cloud forest on rock outcrop versus volcanic soil. J. Veg. Sci. 2020, 31, 129-138. [CrossRef]

61. Bittencourt, P.R.L.; Barros, F.d.V.; Eller, C.B.; Müller, C.S.; Oliveira, R.S. The fog regime in a tropical montane cloud forest in Brazil and its effects on water, light and microclimate. Agric. For. Meteorol. 2019, 265, 359-369. [CrossRef]

62. Guerin, G.R.; Wen, H.; Lowe, A.J. Leaf morphology shift linked to climate change. Biol. Lett. 2012, 8, 882-886. [CrossRef]

63. Williams-Linera, G. Leaf demography and leaf traits of temperate-deciduous and tropical evergreen-broadleaved trees in a Mexican montane cloud forest. Plant. Ecol. 2000, 149, 233-244. [CrossRef]

64. Sack, L.; Frole, K. Leaf structural diversity is related to hydraulic capacity in tropical rain forest trees. Ecology 2006, 87, 483-491. [CrossRef]

65. Rodríguez-Ramírez, E.C.; Sánchez-González, A.; Ángeles-Pérez, G. Current distribution and coverage of Mexican beech forests Fagus grandifolia subsp. mexicana in Mexico. Endanger. Species Res. 2013, 20, 205-216. [CrossRef]

66. Li, Y.; Zou, D.; Shrestha, N.; Xu, X.; Wang, Q.; Jia, W.; Wang, Z. Spatiotemporal variation in leaf size and shape in response to climate. J. Plant. Ecol. 2020, 13, 87-96. [CrossRef]

67. Takahashi, K.; Okuhara, I. Comparison of climatic effects on radial growth of evergreen broad-leaved trees at their northern distribution limit and co-dominating deciduous broad-leaved trees and evergreen conifers. Ecol. Res. 2012, 27, 125-132. [CrossRef]

68. Pederson, N.; D’Amato, A.W.; Orwig, D.A. Natural history from dendrochronology: Maximum ages and canopy persistence of rarely studied hardwood species. In Proceedings of the 15th Central Hardwood Forest Conference, Knoxville, TN, USA; Buckley, D.S., Clatterbuck, W.K., Eds.; University of Tennessee, Wildlife and Fisheries, Knoxville Department of Agriculture Forest Service, Southern Research Station: Knoxville, TN, USA, 2006; pp. 695-701. 
69. Venegas-González, A.; von Arx, G.; Chagas, M.P.; Filho, M.T. Plasticity in xylem anatomical traits of two tropical species in response to intra-seasonal climate variability. Trees Struct. Funct. 2015, 29, 423-435. [CrossRef]

70. Fonti, P.; von Arx, G.; García-González, I.; Eilmann, B.; Sass-Klaassen, U.; Gärtner, H.; Eckstein, D. Studying global change through investigation of the plastic responses of xylem anatomy in tree rings. New Phytol. 2010, 185, 42-53. [CrossRef] [PubMed] article distributed under the terms and conditions of the Creative Commons Attribution (CC BY) license (http://creativecommons.org/licenses/by/4.0/). 